\title{
An endemic gecko in the Caribbean
}

\author{
C. Kenneth Dodd (Jr) and \\ Pedro R. Ortiz R.
}

When the Monito gecko was first discovered in 1974 on Isla Monito in the Caribbean it was apparently threatened by introduced rats. In 1982 a survey by the authors showed that the species is indeed rare and is restricted to two small areas of the tiny island but further work is needed to establish the reasons; the rats are the most obvious, but as yet unproven, cause. Meanwhile the gecko has been listed as endangered by the USA. This alone will not help but it is a start in the conservation of the species.

Isla Monito is $5 \mathrm{~km}$ north-west of Mona Island in the Mona Passage midway between Puerto Rico and the Dominican Republic (long. 67 $57^{\prime}$, lat. $18^{\circ} 10^{\prime}$ ). It is small, $500 \times 300 \mathrm{~m}$, nearly flat on top, but surrounded by nearly vertical cliffs which make landing very difficult. The bases of the cliffs have been undercut by wave action to a distance of $3 \mathrm{~m}$ or more in some places. Rolle et al. (1964) have provided a general description, noting that the island is primarily limestone, although Mitchell (1954) reported rocks which appeared to be pyroclastic on the south side.

Monito is covered with xeric scrub vegetation consisting primarily of cacti, shrubs, and stunted trees (Rolle et al., 1964). Brown boobies Sula leucogaster, red-footed boobies $S$. sula, bluefaced boobies $S$. dactylatra, and noddy terns Anous stolidus nest on the island while magnificent frigate birds Fregata magnificens, sooty terns Sterna fuscata, bridled terns $S$. anaethetus, and yellow-billed tropic birds Phaeton lepturus have An endemic gecko in the Caribbean

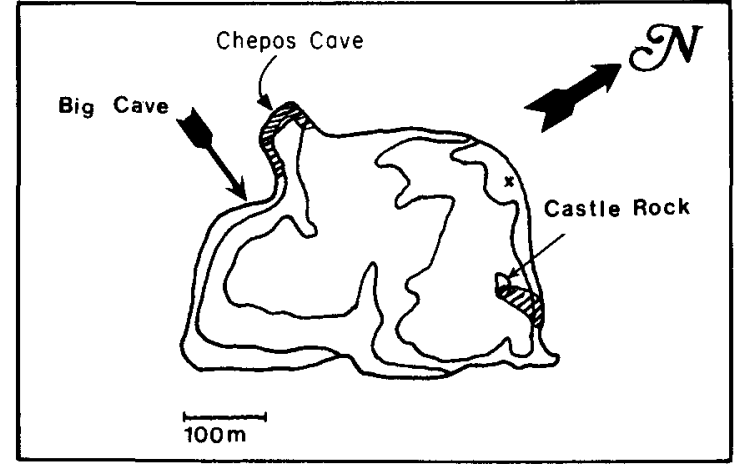

Isla Monito (after Kepler, 1978). The diagonal lines indicate the distribution of the Monito gecko; $x$ marks the highest point on the island $-66 \mathrm{~m}$. The black lines indicate $10 \mathrm{~m}$ contour.

been seen flying overhead. Three species of lizards in addition to the Monito gecko Anolis monensis, Ameiva sp., Mabuya sp., one mammal Rattus rattus, three land molluscs and two fruit flies Drosophila spp. have been reported from the island. Hawksbill and green sea turtles are seen in the offshore waters.

The Monito gecko Sphaerodactylus micropithecus was discovered on Isla Monito in May 1974 by Dr Howard Campbell, who collected an adult (type specimen) and an egg during a twoday visit. The egg later hatched in the laboratory. No further specimens were collected until 1982. In 1974, Campbell reported that

'An ecological factor of considerable concem on Monito is the dense population of introduced rats. No quantitative estimate is available for their numbers, but it should be noted that, at night, one is never out of sight of at least one foraging rat and frequently several 


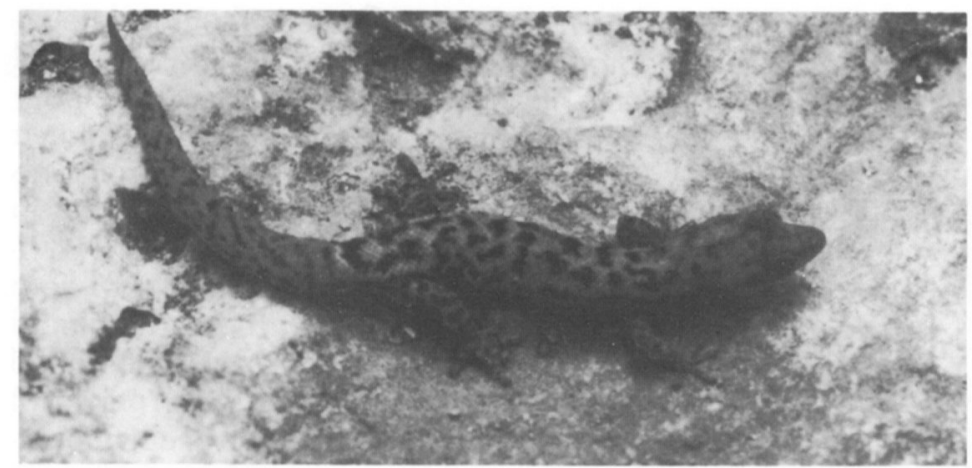

Monito gecko (C. Kenneth Dodd (Jr)).

will be in sight at any given moment. ... The apparent low numbers of Ameiva and Sphaerodactylus might be the result of rat predation. If the Sphaerodactylus turns out to be an endemic species or subspecies and if its numbers are as low as our data indicate, a rat removal program may be necessary for its preservation.'

Previous surveys had not revealed the presence of any lizards of the genus Sphaerodactylus, which are normally abundant members of a herpetofauna when present (Rolle et al., 1964). Schwartz (1977) described the gecko as a distinct species and noted that the Monito Sphaerodactylus was difficult to ally with any geographically proximate species, including $S$. monensis residing only $5 \mathrm{~km}$ away. The apparent rarity of this species, coupled with an abundance of rats (which are known predators on lizards and their eggs), is of concern to herpetologists. Kepler (1978), in his studies of Monito's sea-birds, also noted an abundance of rats on the island and speculated that the absence of Audubon's shearwater on Monito might be the result of rat predation. After numerous discussions with $\mathrm{Dr}$ Campbell, rats were deemed such a potentially serious threat to the survival of the Monito gecko that it was proposed as an endangered species under provisions of the US Endangered Species Act of 1973 (Dodd, 1980). However, questions were raised during preparation of the final rule as to whether the gecko was indeed rare or even still existed, and a survey was authorized to determine the species's status.

The entire island was thoroughly searched in a two-day period-24-25 August 1982. Rocks, leaf litter, military debris (Monito was a bombing 120 target after World War II and much debris remains), and other surface objects were turned and searched for geckos. If a gecko was sighted, every attempt was made to catch it to measure and photograph it. Air and substrate temperatures were recorded at various times as well as the presence of other species of lizards.

A total of $18 \mathrm{~S}$. micropithecus were observed. Eight (snout-vent lengths $17-36 \mathrm{~mm}$ ) were captured and four preserved; two of these are deposited in the Smithsonian Institution and two retained by the Departamento de Recursos Naturales.

$S$. micropithecus was found in only two locations on Monito (nine individuals each); none was found in the centre of the island although there appeared to be plenty of debris for cover. One population is located in the north-west along a ledge and sea cave ('Chepos Cave') entrance. The other population is on the east rim of the island near Castle Rock. Geckos were found under rocks with a small amount of soil underneath. While air temperatures ranged around $32^{\circ} \mathrm{C}$ in the direct sun at noon, temperatures under rocks were about $26^{\circ} \mathrm{C}$. The geckos were extremely active and difficult to capture; they also readily cast off their tails if grasped.

The more forested areas where cover was abundant lacked Sphaerodactylus. The vegetation of these areas consisted of small groves of Guapira while other areas were completely occupied by numerous bushes, mainly Capparis flexuosa and species of Croton, Eupatorium and Toumefortia (Woodbury et al., 1977). These areas have abundant open patches and numerous rocky refuges, so absence of the gecko

Oryx Vol $17 \mathrm{No} 3$ 
cannot be explained in terms of lack of sunlight or appropriate microhabitats.

A total of eight Mabuya mabouia were observed although none were captured. Many Anolis monensis were seen although only two were captured. No Ameiva alboguttata were observed and we suspect their presence on Monito has not been adequately documented. Kepler (1978) listed the species as occurring on Monito based on the checklist of Schwartz and Thomas (1975). No specimens of this species are known to ever have been collected on Monito.

Rats were observed during the daylight hours and appeared quite tame. A total of 24 were observed in the two-day survey -18 on $24 / 8$ and 6 on $25 / 8$. It may be that the cloud cover on $24 / 8$ was preferable for rat foraging as opposed to the hot sun of 25/8. Rats are also active at night on Monito. One rat was observed feeding on a stack of seeds of Paspalum laxum.

$S$. micropithecus appears restricted to two areas along the margins of Isla Monito, one in the northwest and one in the east. The presence of juveniles and large eggs in a number of females suggest that it is reproducing successfully. We suspect reproduction occurs between at least March through November as suggested by the egg found on 24 May 1974 by Campbell, the gravid females and juveniles found by us on 24 25 August 1982, and the fact that Sphaerodactylus eggs take 2-3 months to hatch (Rivero, 1978). It would be advisable to census the population throughout the year to determine any seasonal fluctuations in reproduction, abundance, feeding habits, food availability, and habitat preferences. Acquiring such information is crucial to developing a management programme and any conservation measures that might be appropriate.

Predator pressure on the gecko cannot be proven from this survey and potential predators, such as rats, must be studied to determine whether they do threaten the species. The teiid Ameiva alboguttata also known to prey on smaller lizards, was not found. We recommend that laboratory experiments be conducted on related species of Sphaerodactylus to determine if predation could affect this species. Available evidence does indiAn endemic gecko in the Caribbean cate that the Monito gecko is restricted in range on tiny Monito and is not abundant; the factors responsible for this seeming rarity remain unknown.

On 15 October 1982, the Monito gecko was listed as an Endangered species under provisions of the US Endangered Species Act of 1973. Placing a species on a list, of course, provides little real protection. Since collecting is not a problem due to Monito's remoteness and difficulty of access, the penalties of the Act per se may not assist in conservation. A Recovery Plan should be developed for the Monito gecko which emphasises a thorough study of its biology and abundance coupled with a possible rat extermination programme on Monito. Unless the rats are eliminated, not only the Monito gecko, but also the important avian cornmunity which uses Monito, will continue to be jeopardised.

\section{Acknowledgments}

We thank Miguel Nieves and Agustin Valido for their assistance in the field. The US Coast Guard provided transportation to Isla Monito. We especially thank Hilda DiazSoltero, Secretary of the Departamento de Recursos Naturales, and the US Fish and Wildlife Service for providing financial and logistic support for this survey.

\section{References}

Dodd, C.K. (Jr) 1980. Proposed listing with endangered status and critical habitat for the Monito gecko. Fedl Register, 45 (206), 70,192-70,195.

Kepler, C.B. 1978. The breeding ecology of sea birds on Monito Island, Puerto Rico. Condor, 80, 72-87.

Mitchell, R.C. 1954. A survey of the geology of Puerto Rico. Tech. Pap. agric. Exp. Sta. UNIV. P.R. No. 13, 1-67.

Rivero, J.A. 1978. The Amphibians and Reptiles of Puerto Rico. Universidad de Puerto Rico, Editorial Universitaria. $154 \mathrm{pp}$

Rolle, F.J., Heatwole, H., Levins, R. and Torres, F. 1964. Faunal notes on Monito Island, Puerto Rico. Carib. J. Sci. 4(1), 321-322.

Schwartz, A. 1977. A new species of Sphaerodactylus (Sauria, Gekkonidae) from Isla Monito, West Indies. Proc. biol. Soc. Wash. 90(4), 985-992.

Schwartz, A. and Thomas, R. 1975. A checklist of West Indian amphibians and reptiles. Spec. Publs Camegie Mus. Nat. Hist. (Pittsb.), 1, 1-216.

Woodbury, R., Martorell L. and Garcia, J. 1977. The flora of Mona and Monito. Bull. Puerto Rico agric. Exp. Stn Rio Piedras, 252, 1-60.

C. Kenneth Dodd (Jr), Office of Endangered Species, US Fish and Wildlife Service, Washington, DC 20240, USA.

Pedro R. Ortiz R., Departamento de Recursos Naturales,

Apartado 5887, Puerta de Tierra, Puerto Rico 00906. 